\title{
Fragmentos de um modelo: pequenas lavouras de café e acumulação de capitais. Franca/São
} Paulo 1890-1914

\author{
Pedro Geraldo TOSI* \\ Rogério Naques FALEIROS** \\ Rodrigo da Silva TEODORO***
}

RESUMO: Este artigo versa sobre a importância da pequena cafeicultura no complexo cafeeiro entre 1890 e 1914. Discutimos aqui as relações de trabalho, as formas de financiamento e o modo como a pequena propriedade se insere neste universo. Utilizamos como fontes prioritárias os contratos de trabalho que envolviam a formação e/ou o trato de cafeeiros e as escrituras de dívidas hipotecárias, ambas lavradas nos Livros Cartoriais, fontes estas ainda não trabalhadas pela historiografia de forma mais sistemática. Desviamos nosso olhar para uma região marcada predominantemente pelas pequenas e médias fazendas produtoras de café, observando a dinâmica da acumulação em um período de expansão e de crise da cafeicultura.

PALAVRAS-CHAVE: cafeicultura; acumulação; trabalho.

\section{INTRODUÇÃO}

Grandes propriedades e grandes proprietários, infinitas lavouras de café e colônias de imigrantes a perder de vista dominam o cenário rural descrito na bibliografia sobre a economia cafeeira, notadamente em trabalhos de cunho teórico preocupados com a formação e o desenvolvimento do capitalismo no Brasil. Mas a realidade do café torna-se mais complexa quando o observador se debruça sobre outros aspectos do chamado "complexo cafeeiro". Ao investigar 0 funcionamento do sistema de crédito, a dimensão das lavouras, as relações sociais estabelecidas entre cafeicultores de diferentes 
portes e as relações de produção estabelecidas na realidade rural, - pesquisador confronta-se com uma paisagem bem mais complexa e multifacetada do que poderiam prever os modelos de análise pautados em binômios do tipo "latifúndio-monocultura".

$\mathrm{N}$ ão estamos aqui afirmando que as grandes propriedades não se situassem numa posição de dominância na dinâmica da cafeicultura paulista, entretanto, é necessário ressaltar que as pequenas e médias lavouras produtoras de café também possuíam uma grande importância nessa dinâmica, importância esta que precisa ser mensurada de uma forma mais adequada por quem se dedicar ao estudo da economia cafeeira. Em outros termos, qual é o papel da pequena cafeicultura no complexo cafeeiro?

Reconhecemos que para o escopo do presente trabalho, 0 importante é demonstrar a forma de operação da pequena cafeicultura, ou seja, minimização de relações de emprego e predominância do trabalho familiar.

U ma cafeicultura operando com trabalho familiar, que se diferencia não só pelas dimensões físicas da unidade de produção, mas para a qual vários indicadores revelam, no contexto da crise 1898-1905, sua presença e sua importância e atestam maiores volumes colhidos nas safras de 1906 e 1907.

As fontes consultadas para a região de Franca (SP) demonstram haver aumento de cafeeiros plantados. Como entender o crescimento na quantidade de pés-de-café cultivados em um contexto de redução de preços e de restrição monetária? Isto se explica pelo acesso de famílias de reduzidas posses à propriedade agrícola (provavelmente famílias de imigrantes?) e pela operação com trabalho familiar, com conseqüente redução nos custos de produção. Para que esse argumento se sustente é necessário lembrar que uma redução de custos só aconteceria se houvesse redução nos custos de reprodução da força de trabalho, ou seja, se houvesse agricultura de alimentos conjugada à cafeicultura.

Poder-se-ia objetar que essa atividade familiar estivesse sendo direcionada ao trabalho em terras de grandes proprietários e que poderiam estar voltadas para a agricultura de alimentos, mas como sustentar este argumento em um contexto restritivo 
do ponto de vista mais amplo da economia? Como sustentar tal possibilidade quando se verifica um declínio generalizado dos contratos de formação e/ou trato de cafeeiros?

Vejamos melhor nossa proposição:

Voltamo-nos ao município de Franca, interior paulista, para verificar esse papel. H istoricamente esta região caracterizouse pela dominância da pequena propriedade, conforme já fora destacado por Lélio Oliveira (1997) e Pedro Geraldo Tosi (2003). Não havia grandes fazendeiros em Franca, já que o maior, em 1901, doutor João de Faria, possuía apenas 185.000 pés de café, quantidade incomparável aos milhões de pés de alguns cafeicultores de Ribeirão Preto, como o coronel Francisco Schmidt, que em 1905 contava em suas fazendas com 6.075.500 cafeeiros, ou a Companhia Dumont, com 3.999 .990 no mesmo ano, ou ainda Martinho Prado Júnior, que possuía 2.112.700 cafeeiros também em 1905 . $^{3}$

Esta característica da cafeicultura de Franca deriva em parte de sua estrutura fundiária e em parte pelo tipo de solo predominante na região, o lato-solo vermelho-amarelo fase arenosa, que diferentemente da terra roxa, não apresentava uma grande fertilidade para a cultura cafeeira. A estrutura fundiária de Franca, não tão concentrada como em outros municípios de maior produção cafeeira, originou-se de duas circunstâncias: em primeiro lugar, da antiguidade do povoamento da região - por entrantes de pequenas posses, que a predispôs a uma maior fragmentação do solo; em segundo lugar, ao fato de seus solos não se adequarem tão bem quanto os de terra roxa à cafeicultura, não atraindo grandes investidores interessados em se estabelecer em grandes fazendas, como ocorreu em Ribeirão Preto, no caso, por exemplo, de M artinho Prado Júnior. ${ }^{4}$

A corrida por terras de melhor qualidade, raras no interior paulista, ${ }^{5}$ logo se iniciara. M artinico, como era conhecido Prado Jr., já em 1868 possuía as fazendas Campo Alto e Santa Cruz, nas proximidades de Mogi-M irim. Pelo fim da década de 1870, estava a caminho de estabelecer sua própria fortuna, tornando-se um dos líderes pioneiros a mover a fronteira do café para 0 "Oeste". Explorou os municípios de São Simão e Ribeirão Preto, 
mandando de lá comentários enaltecendo seu potencial para o café.

Pouco depois da pesquisa pelos municípios do "Oeste", Martinico adquiriu sua primeira fazenda em Ribeirão Preto, batizando-a de "Albertina", em homenagem à sua mulher. Em 1885, mais provavelmente com o dinheiro emprestado por seu pai, Martinho Prado, e com os lucros da Albertina, comprou uma fazenda maior, chamada Guatapará, composta por 6.000 alqueires, ao preço de 70:000\$000. M eio milhão de pés de café foram plantados, número que cresceu gradualmente até perto de dois milhões de cafeeiros por ocasião da Primeira Guerra M undial. Em 1889, os Prado adquiriram sua maior plantação no município de Ribeirão Preto (Sertãozinho, após 1896). Era a fazenda São Martinho, medindo cerca de 14.000 alqueires e chegando a ter 3.400 .000 pés de café. A plantação era considerada a ser a segunda maior no Brasil e a maior em um único bloco de terra. Tratava-se um mundo completo em si mesmo para os seus quatro mil trabalhadores. ${ }^{6}$

\section{EXPANSÃO E CRISE: AS RELAÇÕES DE TRABALHO}

No desenvolvimento da cafeicultura de Franca não se repetiu o padrão verificado em Ribeirão Preto, e não se pode, naquela localidade, partir da premissa de que grandes investidores estavam à frente da produção cafeeira. ${ }^{7}$ Do ponto de vista dos detentores de grandes capitais, Franca constituía uma espécie de periferia no conjunto dos municípios paulistas produtores de café, e nunca, na sua história, se destacara pelo volume de sacas produzidas.

Em uma realidade dominada marcadamente pelas pequenas e médias propriedades - já que volumes na casa dos milhões de cafeeiros plantados, necessária e suficientemente requeriam grandes propriedades para a sua plantação - , como se organizava a economia cafeeira? Em virtude das múltiplas questões a serem consideradas, vamos iniciar pelas relações de trabalho. A cafeicultura local atingiu escalas de produção capitalista na década de 1890, conforme podemos verificar no gráfico que se segue. Se atentarmos para o fato de que Franca 
recebeu uma ligação férrea em 1887, concluiremos que a inauguração da Estação da Mogiana na cidade tornou-se imprescindível para viabilizar o aumento da produção cafeeira.

Também na década de 1890 houve maiores proporções na vinda de imigrantes para o município, destacando-se os italianos, que em grande medida alocaram-se nas fazendas de café na condição de colonos. Como Franca não se mostrou propícia ao surgimento de grandes lavouras cafeeiras, também não atraiu grandes levas de imigrantes em comparação com outras regiões melhor dotadas de recursos naturais. De fato, enumerar os municípios mais procurados pelos imigrantes seria simplesmente repetir a lista dos centros cafeicultores na ordem de sua importância. E entre 1901 e 1920, Franca recebeu 7.065 imigrantes, número que não se compara aos 22.987 imigrantes registrados em Jaú no mesmo período, e muito menos aos 37.149 registrados em Ribeirão Preto, ${ }^{8}$ salientando-se 0 fato de que também na década de 1890 a cafeicultura destes municípios ampliou-se consideravelmente.

GRÁFICO 1 - Café embarcado na estação Franca da Mogiana em 1888-1917

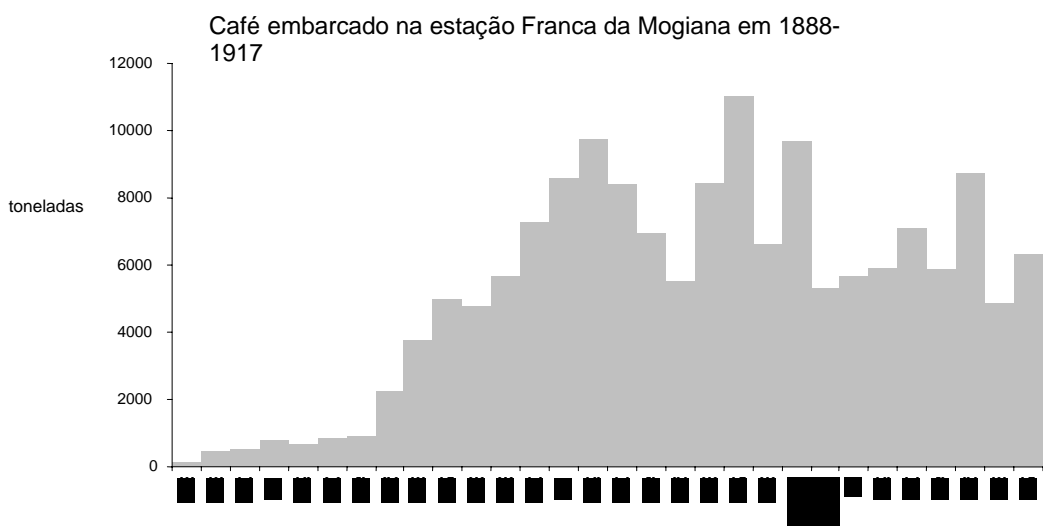

FONTE: adaptado de Pedro Geraldo TOSI. Capitais no interior: Franca e a história da indústria coureiro-calçadista (1860-1945). Franca: FHDSS, Unesp, 2003, p.303. 
Em que medida as relações de trabalho estabelecidas em Franca divergiam ou convergiam em relação às estabelecidas em outras regiões? $\mathrm{N}$ a verdade elas convergiam, pois verificava-se em Franca, assim como em outros locais, a predominância do colonato. O que é o colonato? É quase unânime a resposta: Verena Stolcke (1986), Thomas H olloway (1984), Brasílio Sallum Jr. (1982) e José de Souza M artins (1979) o definem como uma combinação de salário anual, ganhos por empreitada e acesso às lavouras de subsistência. N as palavras de Sallum J r., no colonato

[...] as pessoas se comprometiam, por contrato, a realizar certo número de tarefas pelas quais recebiam remuneração em dinheiro. Basicamente tais tarefas consistiam em: cultivo anual de certo número de pés de café, pelo qual recebiam uma remuneração em dinheiro, variável segundo o número de pés e paga em parcelas trimestrais, bimestrais ou mensais, participação na colheita, pela qual auferiam dinheiro conforme a quantidade apanhada e entregue; serviços extraordinários, à parte do cultivo do cafezal e da colheita, pelos quais recebiam segundo o tempo de trabalho - dias ou horas - ou, eventualmente, conforme as tarefas executadas". ${ }^{9}$

Constitui-se o colonato na soma de três condições: trabalho anual, empreitada, e acesso a terrenos para plantio de alimentos. As duas primeiras são monetárias, e a terceira é um paliativo para o rebaixamento dos gastos monetários com os trabalhadores.

Sob as condições acima descritas dava-se a contratação de trabalhadores para "tocarem" o café nas fazendas. Os contratos de trabal ho eram registrados nos cartórios de registro civil; nestas escrituras definiam-se as formas de remuneração, o acesso à terra, o local e a autorização de plantio de outras culturas, tais como o arroz, o milho e o feijão, o prazo de duração, os termos de garantia, os adiantamentos. $\mathrm{N}$ a pesquisa realizada por Rogério Naques Faleiros (2002) ${ }^{10}$ foram analisadas 270 escrituras de contratos de café entre 1866 e 1920; destas, 128 foram registradas entre 1890 e 1900, período ápice da cafeicultura local. 
GRÁFICO 2 - Contratos de formação e/ou trato de café lavrados em Franca (1866-1920)

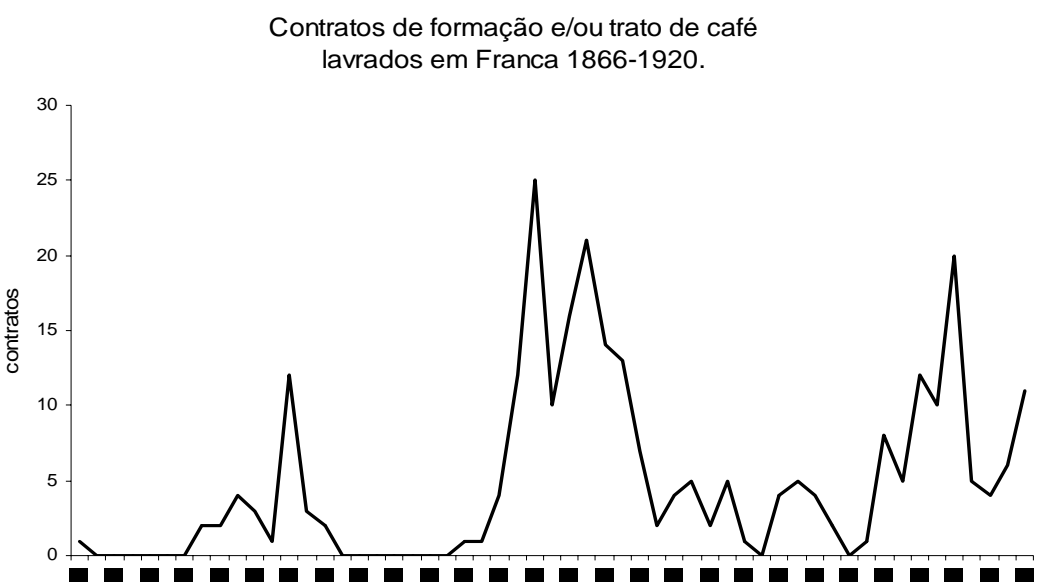

Fonte: Adaptado de Rogério Naques FALEIROS. Homens do Café: Franca 1880-1920. Campinas, 2002, p.24. Dissertação (Mestrado) - IE/Unicamp.

O sistema de colonato sempre se estabeleceu em áreas de fronteira, notadamente onde está em jogo a formação de novas lavouras. Observando os contratos constatamos que ao decidir formar uma nova lavoura os fazendeiros reduziam seus gastos permitindo aos colonos o acesso à terra. Do ponto de vista do fazendeiro, ceder terras aos colonos significava certa autonomia em relação ao movimento dos preços, uma vez que se diminuía a composição monetária da renda do colono; em momentos de preços altos da saca do café, aumentava-se a renda dos fazendeiros; em momentos de baixa, mesmo com a renda deprimida, estes poderiam continuar formando novas lavouras, pois, na base, gastos monetários se efetivavam reduzidamente. 0 monopólio da terra garantia a sobrevivência e até mesmo a expansão das lavouras de café, inclusive em cenários nãosatisfatórios.

Pensemos: Qual é o custo para se formar uma nova lavoura de café? $\mathrm{Na}$ década de 1890, o governo paulista subsidiava as passagens transatlânticas, bem como a hospedagem inicial e 0 
transporte ferroviário até as fazendas que demandavam trabalhadores. Lá chegando, os trabalhadores eram alocados nas casas de colônia, e em determinadas situações, os próprios trabalhadores construíam as casas, arranchando-se em moradias precárias nas primeiras semanas. Cada núcleo familiar, em contrato, assumia um talhão e se responsabilizava pela formação e trato de alguns milhares de cafeeiros. Autorizava-se o plantio intercafeeiro, e ao final de quatro ou cinco anos pagava-se uma determinada quantia por cova formada. Foi o caso de Jácomo Zulcarelli, contratado em 1896 por Luiz Pinto Bastos para formar 12.000 cafeeiros, recebendo $0 \$ 700$ por cova formada ao final de quatro anos, ${ }^{11}$ ou seja, uma quantia total de 8:400\$000 ao término do contrato, além de, teoricamente, dispor de toda a produção dos cafeeiros no quarto ano e da totalidade da produção de alimentos. Podemos perceber que após quatro anos o fazendeiro teria uma lavoura adequadamente formada e em plena produção, com um mínimo custo monetário.

Os doze mil pés formados seriam viavelmente produtivos por pelo menos quinze anos. Considerando a produtividade dos cafeeiros francanos, estimada em 154,02 arrobas por mil pés em 1902, e considerando a cotação em Santos de $4 \$ 200$, apontada por Thomas Holloway para o mesmo ano, Luiz Pinto Bastos receberia 7:762 $\$ 608,{ }^{12}$ vale dizer, em apenas um ano de colheita arcaria praticamente com todas as despesas de formação dos doze mil pés, restando, para o seu bolso, toda a produção daqueles cafeeiros nos próximos catorze anos. $\mathrm{N}$ ão era necessário ser um grande proprietário para formar lavouras desse calibre.

Do ponto de vista do colono, e de sua família, por suposto, dedicar-se a outras culturas significava garantir a própria subsistência, além do que poderia capacitá-lo a atuar no mercado, vendendo os excedentes de sua produção alimentícia (milho, feijão, banha, toucinho e arroz) no meio urbano, ou mesmo nas mercearias existentes no meio rural. Geralmente 0 colono também tinha direito à produção dos cafeeiros no último ano de contrato, o que pouco pesava nas suas contas, visto que a produtividade de cafeeiros entre quatro e cinco anos de idade ainda não atingira todo o seu potencial. 
Parte da bibliografia liga as possibilidades de ascensão social dos colonos à mercantilização do excedente de alimentos por eles cultivados. Nas palavras de Thomas H olloway:

Em muitos casos, os cereais e animais excedentes que o colono vendia proporcionavam uma importante fonte adicional de dinheiro. Tal renda extra podia ser adicionada às economias ou usada para comprar os itens não produzidos na fazenda, tal como farinha de trigo, açúcar, querosene, roupas e ferramentas. Como exemplo da importância que os próprios trabalhadores atribuíam ás porções não monetárias do contrato de trabalho, um Vice-Cônsul italiano em Ribeirão Preto constatava, em 1903, que os colonos preferiam uma fazenda onde os salários em dinheiro eram pequenos, mas onde os privilégios de lavoura de alimentos e criação de animais eram generosos, a uma fazenda onde os salários eram melhores, mas sendo restritos os privilégios não monetários. Um observador francês anotava em 1909: "o que realmente permite que os colonos acertem o deve e o haver são as plantações que eles tem o direito de fazer por sua própria conta [...]. Eles muitas vezes se preocupam mais com as cláusulas do contrato relacionadas com essas plantações do que com aquelas que determinam seus salários em dinheiro". ${ }^{13}$ (grifos nossos).

Segundo Faleiros, seria um mito acreditar que os colonos disporiam livremente do café e dos alimentos por eles produzidos. 0 autor identifica o que poderíamos chamar de um "estreitamento de mercado" na comercialização dos excedentes produzidos pelos colonos. Complexos mecanismos atuavam no sentido de impedir os colonos de praticar os preços vigentes na praça, pois os fazendeiros interpunham-se entre estes e os compradores, estabelecendo nos contratos de café cláusulas que garantiam a "preferência de venda" dos gêneros alimentícios à fazenda. Estas cláusulas foram encontradas na maioria das quase trezentas escrituras pesquisadas pelo autor. Como exemplo, podemos citar o caso de M anuel Alves de Souza, que em 1893 foi contratado por José Theodoro de Mello para formar 12.000 cafeeiros na Fazenda Palmital. ${ }^{14}$ Nos quatro anos de contrato, 0 colono teria direito à prática do cultivo intercafeeiro, entretanto, 
não poderia comercializar livremente a sua produção de alimentos, pois a escritura assinada por ambos determinava a "preferência de venda" a José Theodoro de Mello. Isto, numa sociedade hierarquizada onde o chefe da fazenda reunia em torno de si um grande número de agregados, entre eles os novos colonos, significava dizer que o trabalhador necessariamente teria que vender sua produção de alimentos ao proprietário.

A relação entre ambos tornava-se lucrativa ao fazendeiro sob dois aspectos: por um lado, ele garantia a formação de uma nova lavoura de café, e por outro, concentrava a comercialização dos alimentos produzidos pel os colonos numa relação cujas bases eram o monopólio do mercado e o estreitamento das relações de troca, sendo a finalidade o enriquecimento via intercâmbios desiguais. Tinha-se, então, um mecanismo em que o colono, na terra intercafeeira, promovia a sua subsistência mas perdia 0 excedente, ou sua maior parte, ao "negociá-lo" com o fazendeiro. Feito isto, este vendia os produtos no mercado e lucrava com a inequivalência dos preços. Ao contrário de Holloway, é difícil imaginar que os preços correntes no mercado orientassem as negociações estabelecidas entre fazendeiros e colonos.

Corrobora este argumento o fato de que as quantidades de alimentos embarcadas na estação Franca, da Mogiana, cresciam consideravelmente na medida em que a cafeicultura avançava no município. Se os colonos realmente se encarregassem da colocação de arroz, milho, feijão, etc., no mercado, nos depararíamos com uma rede comercial pulverizada, onde múltiplos produtores participariam dos jogos das trocas. Contudo, observamos justamente o contrário.

O gráfico 3 revela que as quantidades de alimentos “exportadas” pelo município foram crescentes a partir da década de 1890. Certamente estes alimentos foram cultivados por colonos nos espaços intercafeeiros, revelando que o próprio crescimento das lavouras de café proporcionava o incremento da produção de outras culturas. Chegou-se a "exportar” quase três mil toneladas de gêneros alimentícios em 1898, mas tal volume de comércio não se realizaria se não fosse amparado e precedido por uma intensa concentração dessas redes mercantis. 
Certamente os comerciantes e as casas comerciais sediadas na cidade constituíam o elo final de toda uma cadeia que se iniciava com a produção dos colonos, passava pelas mãos dos fazendeiros, para finalmente chegar aos agentes urbanos que escoavam essa produção até os centros consumidores de maior vulto.

GRÁFICO 3 - Gêneros Alimentícios embarcados na Estação Franca, da Mogiana, em 1888-1917 (exclusive café)

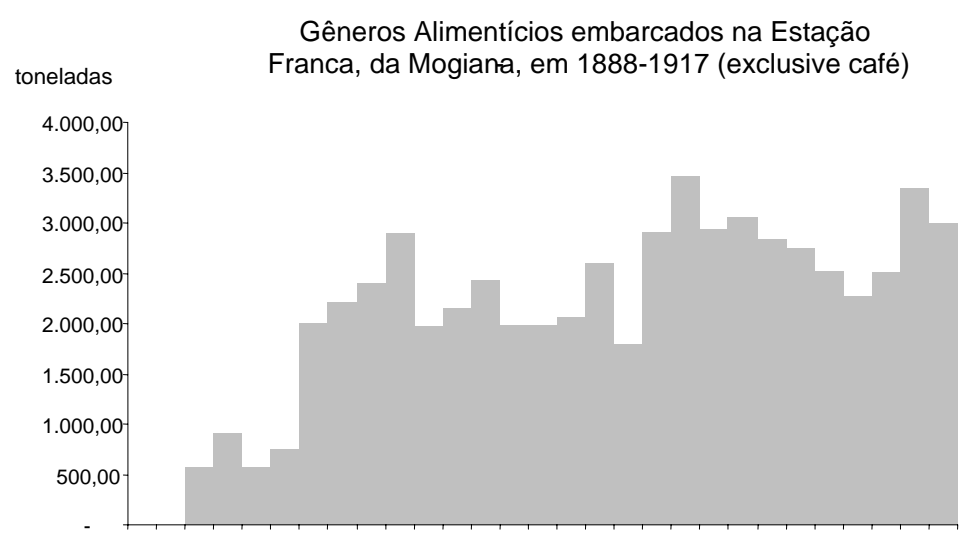

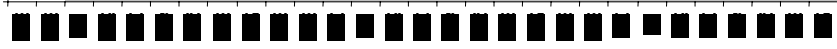

FONTE: Adaptado de TOSI, Pedro Geraldo. Op. cit., p.90.

Encontramos ainda um indício empírico da centralização do comércio de alimentos operada pelos fazendeiros de café. No inventário de Joaquim Garcia Lopes da Silva Júnior, ${ }^{15}$ datado de 1911, notamos que em suas três fazendas: Santa Amélia, Jaguarão e dos Buritys, o inventariado possuía uma certa quantidade de cereais estocados; na Santa Amélia, 500 sacos de arroz avaliados em 5:500\$000, 25 carros de milho avaliados por 425\$000, e 80 sacos de feijão que montavam a $160 \$ 000$; no Jaguarão, 8 carros de milho na roça a $200 \$ 000,7$ carros de milho no paiol a 
245\$000, e 20 sacos de feijão ainda por colher a 40\$000; nos Buritys, 30 carros de milho no paiol a 1:050\$000.

Wilson Cano afirma que a produção mercantil de alimentos foi um componente prioritário na formação e consolidação do complexo cafeeiro. Segundo o autor, a agricultura de alimentos era totalmente dependente da atividade nuclear, o café, e portanto, tinha autonomia muito relativa. Estava vinculada, em síntese, às sobras e aos tempos que sobravam de recursos semi-utilizados pelo café. Entendida desta forma, vemos que seu desenvolvimento tendia a um limite ditado pela atividade nuclear. À medida que o complexo cafeeiro se desenvolvia e gerava um processo crescente de urbanização, o sistema reclamava também, ainda segundo Cano, a expansão da agricultura independentemente da atividade nuclear, ou seja, aquela feita fora da propriedade cafeeira, operando com os seus próprios recursos físicos. ${ }^{16} \mathrm{O}$ autor pressupõe que o crescimento das cidades demandaria "indústrias agrícolas" especializadas na produção de alimentos, notadamente pequenas propriedades que se dedicariam ao cultivo de milho, arroz e feijão. Acreditamos que esta realidade pode ser verificada nos municípios da Grande São Paulo, tais como M ogi das Cruzes e Santa Izabel, principais abastecedores de alimentos da capital, entretanto não acreditamos que tenha existido uma separação rígida entre unidades produtoras de café e unidades produtoras de alimentos no "Oeste Paulista", tal como sugerido pelo autor. O caso de Franca, bem como de Campinas, Ribeirão Preto, Rio Claro, São José do Rio Preto e Catanduva, onde al gumas pesquisas cartoriais realizadas por Faleiros $(2005)^{17}$ demonstram que mesmo em período mais avançado ao aqui tratado, o cultivo conjunto do café e outros gêneros alimentícios foi largamente utilizado, notadamente na fronteira.

Mas se já podemos em questão o que seria a principal possibilidade de acumulação dos colonos e, por conseguinte, a ascensão à condição de proprietário, como explicar o surgimento da pequena, e mesmo da propriedade fundiária de dimensões diminutas, já que estas, em grande parte da bibliografia, ${ }^{18}$ têm por origem a frugalidade e a diligência pessoal dos trabalhadores do café, notadamente os imigrantes? Esta origem se aclara, no 
entanto, se nos voltarmos para os impactos da conhecida crise de superprodução que se abateu sobre a lavoura cafeeira no final do século XIX.

Os impactos da crise de superprodução fizeram-se sentir nas relações de trabal ho estabelecidas entre fazendeiros e colonos naquele contexto. Segundo Augusto Ramos, a situação da lavoura paulista era mais difícil, do ponto de vista financeiro, do que a dos demais produtores; em São Paulo predominava o colonato, enquanto nos demais Estados predominava a parceria:

[...] em São Paulo o preço do trabalho do colono é ajustado por mil cafeeiros no tratamento dos mesmos, por alqueire de 50 litros de café no trabalho de apanha, e por dia nos serviços avulsos [...] ele aufere também indiretamente vantagens de outra ordem e de maior valor. São as que resultam da cultura de cereais, feijão, etc., entre as filas dos cafeeiros. [...]. Em outras regiões como a fluminense e M inas Gerais é freqüente serem as lavouras confiadas às famílias de colonos pelo sistema de trabalho por porcentagem ou parceria das colheitas, em geral a meias, isto é, cabendo a cada família, como remuneração por cuidar dos cafeeiros e fazer a colheita, metade do que esta produzir. $^{19}$

Essa diferença regional implica que os valores financeiros envolvidos eram previamente estabelecidos em uma forma de trabalho e em outra não. Na parceria, dominante em M inas e no Rio de Janeiro, a remuneração do colono estava submetida à realização do valor mediante as condições do mercado, já os fazendeiros paulistas, por contratarem previamente as cláusulas envolvendo dinheiro, submetiam-se ao descompasso entre a quantia envolvida na relação com o colono e o preço de mercado, o que, no contexto de superprodução, significava que os fazendeiros de São Paulo, como um todo, estavam acumulando prejuízos, fato atenuado nas terras de fronteira onde a produtividade equilibrava um pouco mais as contas.

Sob um outro aspecto, as relações de colonato também pressionavam os cafeicultores. As terras para o plantio de outros alimentos eram fornecidas na proporção do cafezal envolvido na negociação, e uma vez que lavouras novas não estavam sendo 
formadas, os fazendeiros não tinham condições de fornecer aos colonos novas terras para esses plantios. Tal argumento baseia-se no fato de que o colonato é uma relação de trabalho própria de um contexto de expansão das lavouras. 0 colonato pressupõe 0 movimento da fronteira.

Isso significa que o mecanismo de acesso à terra, antes usado para rebaixar os custos monetários, estava ficando "engessado", aumentando para os colonos a importância das cláusulas envolvendo dinheiro, justamente o que faltava nos anos de Campos Salles como presidente (1898-1902). No colonato a queda do preço do café recaía inteiramente sobre o fazendeiroproprietário; na parceria era dividida, e mesmo que para este não fosse lucrativo ficar com apenas metade da produção, era positivo o fato de não assumir dívidas maiores com os colonos. Convenhamos, num momento de superprodução efetuar pagamentos com café aos colonos (parceria) constituía uma funcional estratégia utilizada pelos fazendeiros. Em conseqüência da crise, o número de contratos de formação e/ou trato de café em Franca diminuiu drasticamente (ver gráfico 2). Ao mesmo tempo, os cafeeiros plantados no início da década de 1890 atingiram 0 auge de produtividade, exportando-se quase dez milhões de toneladas em 1902.

No apogeu da crise, em 1905, não foi lavrado nenhum contrato de trabalho. As exportações de café reduziram-se a pouco menos de seis milhões de toneladas, chegando ao ponto máximo da decadência iniciada em 1903. Em 1906, com a intervenção estatal, o número de contratos lavrados começou novamente a subir e a exportação de café acompanhou este movimento, marcando a recuperação das lavouras prejudicadas anteriormente com a geada de 1902.

As conseqüências do período de retração 1898-1905 redimensionaram as propriedades em Franca. M últiplas falências foram registradas no contexto da política deflacionária de Murtinho, ministro de Campos Salles. As maiores plantações do município foram praticamente varridas do mapa. Custos elevados e preços cadentes resultaram no abandono e desvalorização das propriedades, bem como em movimentação 
de trabalhadores em direção às zonas novas. Interessantes são os números apontados por Pedro G. Tosi:

No que concerne ao fracionamento e reconcentração das propriedades rurais no período em tela [1905-1920], interessa qualificar que houve um continuado decréscimo no tamanho médio das propriedades: de 159 alqueires em 1905 para $110 \mathrm{em}$ 1920. [...]. O número total de propriedades oscila de $384 \mathrm{em}$ 1905 para 583 em 1920, enquanto o tamanho das propriedades foi sendo diminuído. A pesar disso, aumentava o número total de cafeeiros plantados, bem como a área cultivada, embora nem sempre fosse crescente a média de cafeeiros por estabelecimento. ${ }^{20}$

O que os dados deste autor evidenciam é um verdadeiro fenômeno de fragmentação da propriedade; os "grandes cafeicultores" atingidos em cheio pela crise desfizeram-se de porções de terras para saldar suas dívidas e ainda, segundo o autor,

foi no período entre 1906 e 1915 que imigrantes, principalmente de origem espanhola e italiana, credores de dívidas para com os velhos cafeicultores, dotados de alguma economia e famílias numerosas, tiveram acesso à propriedade de terras de dimensões não muito elevadas. Começaram, então, a aparecer os sitiantes e pequenos fazendeiros de origem estrangeira. 0 produto, contudo, não deixara de ser a base da economia local: já em 1915, em virtude da mudança na estrutura fundiária, era possível verificar o aumento do número de cafeeiros. ${ }^{21}$

\section{CRÉDITO E ACUMULAÇÃO: O PAPEL DA PEQUENA}

\section{CAFEICULTURA}

Até aqui explicitamos a forma como operavam as médias propriedades e o contexto em que se dava o surgimento das pequenas, estas baseadas, em geral, no trabalho familiar. Mas de imediato outra questão se apresenta: Qual a funcionalidade dessas pequenas propriedades no conjunto da economia cafeeira? Para chegar à raiz do problema, devemos analisar os movimentos 
próprios dessa economia, de modo a privilegiar o processo de acumulação vis-à-vis nas formas de financiamento dos produtores, pois se constitui em um setor vital para a compreensão dessa dinâmica.

Cabe salientar, a partir do estudo de Flávio Azevedo $M$ arques de Saes sobre o sistema bancário paulista na Primeira República, que os fluxos de crédito oriundos deste dificilmente se dirigiam à lavoura e que, na verdade, os grandes bancos nacionais sediados na cidade de São Paulo preferiam concentrar suas operações de empréstimos nos empreendimentos comerciais de algum porte que atuavam na própria capital e em Santos, dada a maior lucratividade, a maior solvência e, conseqüentemente, o menor prazo de retorno do investimento que estas atividades ofereciam em comparação à produção de café. ${ }^{22}$ Os bancos estrangeiros, por sua vez, dedicavam-se ao financiamento da dívida pública, dos investimentos ferroviários e industriais. Os bancos do interior, em geral, eram inexpressivos no que dizia respeito ao seu volume de capitais e, portanto, mais suscetíveis às intempéries próprias das flutuações da economia cafeeira. Os bancos hipotecários, por sua vez, eram poucos e comumente privilegiavam suas carteiras comerciais em detrimento dos empréstimos garantidos por hipotecas, principal modalidade de crédito utilizada pelos lavradores.

Assim, percebemos que os cafeicultores deveriam possuir acesso a alguma fonte de crédito não oriunda do sistema bancário, já que é difícil pensar num sistema de autofinanciamento dos fazendeiros, dada a natureza do cafeeiro, cujos frutos só aparecem após o quarto ou quinto ano de cultivo. A questão é: De onde provinha esse crédito? Devemos nos voltar agora para um personagem que a bibliografia tem apontado como fundamental para o financiamento da cafeicultura: 0 comissário.

O comissário surge como um intermediário entre 0 fazendeiro e o exportador na venda do café. $\mathrm{Na}$ verdade, o comissário não agia apenas como um mero representante comercial, embora inicialmente suas atividades tenham se restringindo a tal função. Também fornecia a seus clientes vários artigos de que necessitavam, oriundos dos grandes centros 
urbanos, mas sua centralidade na economia cafeeira advinha da posição que ocuparam no fornecimento de crédito para a lavoura, que se impôs ao comissário praticamente como uma exigência para a prosperidade de seus negócios, já que o fazendeiro, conforme já ressaltamos, dificilmente dispunha de condições para se autofinanciar. ${ }^{23}$ Também percebemos a atuação, nas cidades do interior, além do comissariado, de uma camada de financistas locais que ficaram conhecidos como "capitalistas", denominação que denotava, na verdade, a posse de dinheiro disponível para empréstimos. Apesar da atuação porventura diferenciada que comissários e capitalistas possam ter apresentado, e que não cabe aqui discutir, havia algo em comum entre ambos que trazia sérias conseqüências para a lavoura cafeeira: as al tas taxas de juros cobradas e o curto prazo praticado nas operações de crédito, como observamos nos gráficos a seguir:

GRÁFICO 4 - Prazos praticados nos empréstimos registrados em Franca (1888-1914)

Prazos praticados nos empréstimos registrados em Franca por períodos selecionados

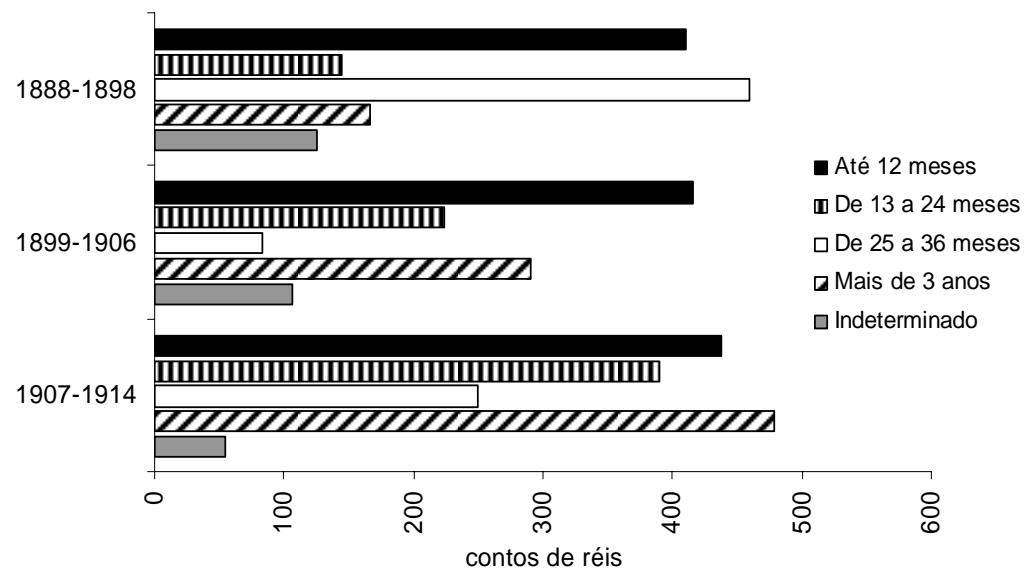

FONTE: Livros de Notas do $2^{\circ}$ Ofício Civil de Franca, 1888-1914. In: TEODORO, Rodrigo da Silva. O Crédito no mundo dos senhores do café. Franca 1885-1914. Campinas, 2006, fl.144. Dissertação (Mestrado) - IE/Unicamp. 
GRÁFICO 5 - Taxas de juros praticadas nos empréstimos registrados em Franca (1880-1914).

Taxas de Juros praticadas nos empréstimos registrados em Franca por períodos selecionados

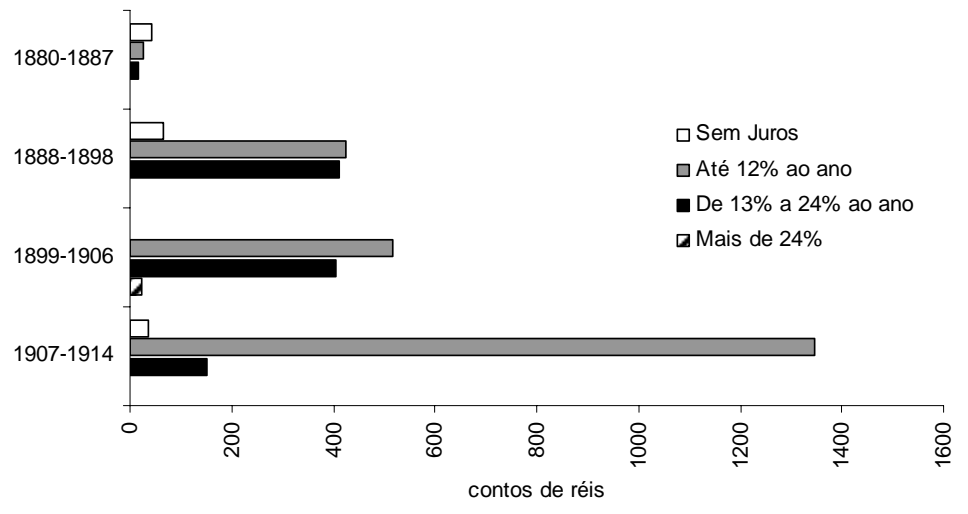

Fonte: Idem, fl.138.

Pode-se perceber, em ambos os gráficos, uma melhora nas condições de financiamento da lavoura no intervalo de 1907 a 1914. Ao lograr êxito na fixação dos preços do café em um patamar superior ao passado, e acenar com possibilidades de uma maior estabilidade no movimento dos preços, o plano de valorização de 1906 garantiu mais segurança para os credores durante este período, permitindo o estabelecimento de prazos maiores e taxas de juros mais aprazíveis. Entretanto, o crédito continuava caro aos tomadores, pois nem de longe satisfazia às necessidades dos investimentos na cafeicultura, que demandavam prazos mais dilatados, pois apenas registrariam lucros quatro ou cinco anos depois de realizadas as primeiras despesas.

0 Banco de Crédito Real de São Paulo, fundado em 1882 e liquidado em 1906, por exemplo, emprestava a $8 \%$ para prazos de cinco a dez anos e $9 \%$ de quinze a vinte anos, vão obstante uma série de exigências na efetivação do crédito que 
desestimulava a captação por parte dos cafeicultores. ${ }^{24}$ Renato Leite $\mathrm{M}$ arcondes, analisando as taxas de juros no Vale do Paraíba, identificou que em Lorena, nos anos compreendidos entre $1850 \mathrm{e}$ 1872 , as taxas atingiram em média $16 \%$ ao ano. Não obstante, 0 comportamento da taxa de juros, entre 1865 e 1887, parece apontar para uma progressiva redução, o que $\mathrm{M}$ arcondes atribui à penetração do capital bancário. ${ }^{25} \mathrm{O}$ autor percebe que durante a crise de $1874 / 1876^{26}$ as taxas de juros apresentaram-se discrepantes entre os município de Lorena, onde aumentaram, e Guaratinguetá, onde se mantiveram estáveis, provavelmente pela chegada do capital bancário nesta localidade antes que em Lorena. Na segunda metade da década de 1860, a taxa de juros para o crédito hipotecário chegou à casa dos $14 \%$ ao ano nos dois municípios, vindo a oscilar entre 11 e 10\% entre 1879 e 1886, atingindo 9,5\% em 1887. Este exemplo também evidencia a discrepância das taxas de juros praticadas pelo setor institucionalizado (bancos) e o crédito informal (comissários e "capitalistas").

Os cafeicultores, contudo, não apenas sofriam o efeito das altas taxas de juros em suas contas, mas também se encontravam, ainda que indiretamente, expostos a todo tipo de crise que porventura atingisse 0 sistema financeiro. $A$ inexistência de um 
banco de redescontos ${ }^{27}$ implicava a manutenção, pelo sistema bancário, de uma elevada proporção de caixa para fazer frente às situações adversas, de modo que, segundo Saes, havia uma quantidade maior de dinheiro em poder do público que nas instituições bancárias. Esta estrutura, associada à centralidade do grande capital cafeeiro ${ }^{28}$ nessa economia, conferia uma enorme fragilidade ao sistema bancário em contextos em que atuavam conjuntamente dificuldades de realização do café no mercado internacional, crise nas contas públicas e políticas contracionistas, muitas vezes derivadas da postura governamental diante da própria conjuntura econômica. Como havia a possibilidade de os comissários e "capitalistas" captarem recursos no sistema bancário, uma carência de numerário deste poderia repercutir sobre a cafeicultura. Era neste sentido que uma política de "enxugamento" do meio circulante se espraiava pelo conjunto econômico.

Destarte, é bastante compreensível que a cafeicultura pudesse se expandir e mesmo encontrar alguma facilidade em saldar seus débitos em uma conjuntura de abundante liquidez, inflação de preços e desvalorização cambial - já que esta permitiu a manutenção, ou mesmo a ampliação da renda em moeda nacional dos agentes exportadores num contexto de queda dos preços internacionais do café - como foi o período conhecido como "Encilhamento", cujos efeitos se estenderam pelo menos até 1898, porquanto o fazendeiro não apenas encontrava maior facilidade no acesso ao crédito, como era auxiliado pela própria progressão da queda do câmbio e da depreciação do dinheiro. Entretanto, como a cafeicultura conseguiu absorver os impactos da crise?

Observamos no gráfico um que a cafeicultura do município de Franca se ressentiu dessa crise de numerário, tanto que as quantidades de café embarcadas na estação Franca reduziram-se drasticamente a ponto de passarem de um patamar de cerca de 9.700 toneladas em 1902 para cerca de 5.500 toneladas em 1905. Contudo, já em 1906, ano no qual ainda não haviam se dissipado os efeitos da superprodução, acrescida da premente escassez de moeda que caracterizou o início do século XX, as quantidades embarcadas sobiram para cerca de 8.500 toneladas, atingindo 0 
ápice em 1907: 11.000 toneladas de café. Ora, não podemos atribuir este aumento nas quantidades embarcadas nos anos de 1906 e 1907 simplesmente aos cafeeiros formados antes de 1898, pois neste caso as quantidades produzidas nos anos imediatamente posteriores a 1902 equiparar-se-iam às quantidades produzidas neste ano. 0 que estamos tentando dizer é que se registrou em 1907 uma quantidade de toneladas embarcadas maior do que em 1902, logo, pode-se inferir que cafeeiros foram formados durante a crise. Como explicar?

Os financistas locais, por algum meio, não sofreriam as conseqüências da falta de numerário promovida pelas políticas governamentais de teor contracionista que lhes permitisse seguir fornecendo crédito à lavoura? Ou seja, a escassez monetária atingiria também esta camada de usurários? Certamente. 0 gráfico abaixo corrobora este argumento com dados empíricos.

GRÁFICO 6 - Volume de empréstimos efetivamente tomados em Franca (1889-1914).

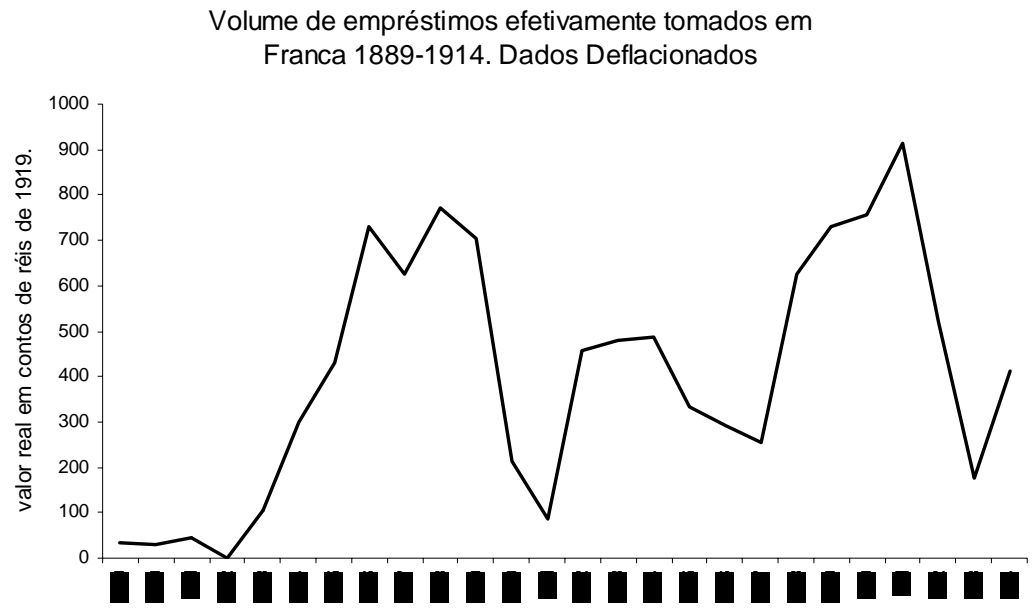

FONTE: Livros de Notas do $2^{\circ}$ Ofício Civil de Franca, 1880 a 1914, $\mathrm{n}^{\circ} 5$ ao 79 . In: TEODORO, Rodrigo da Silva. Op. Cit., cap.III. Valores deflacionados a partir de VILLELA, Annibal V.; SUZIGAN, Wilson. Política do governo e crescimento da economia brasileira 1889-1945. 3.ed. Rio de Janeiro: IPEA/INPES, 2001, p.433. 
Permanece a questão: Como é possível a expansão da cafeicultura mesmo com uma severa restrição creditícia? A mudança no regime de trabalho do colonato para a parceria explica parcialmente a questão, mas como podemos perceber pelo gráfico 2, houve poucos contratos de trabalho lavrados em cartório entre 1899 e 1911, demonstrando que esta não foi a via, ou a principal via, de expansão da lavoura cafeeira naquele período. Talvez um olhar mais verticalizado sobre a estrutura do crédito elucide a questão. O bservemos o gráfico que se segue:

GRÁFICO 7 - Proporção dos créditos registrados em Franca (18801914)

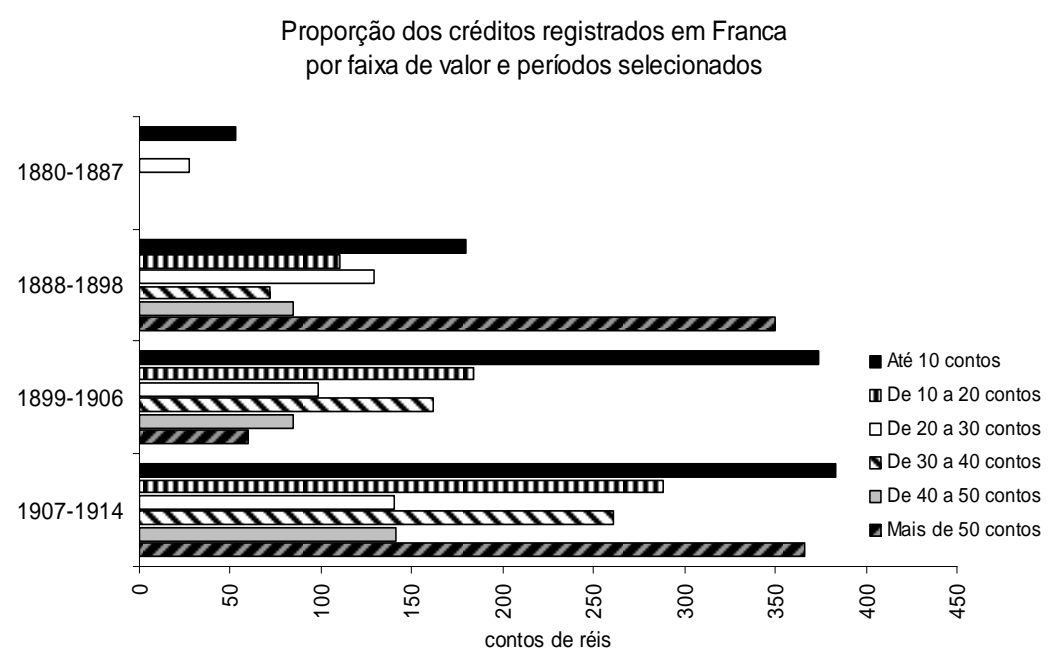

Fonte: Livros de Notas do $2^{\circ}$ Ofício Civil de Franca, 1880 a $1914, \mathrm{n}^{\mathrm{o}} 5$ ao 79 . In: TEODORO, Rodrigo da Silva. Op. cit., cap.III. Somamos o valor de todas as escrituras em cada faixa.

O que salta aos olhos no tocante ao período compreendido entre 1899 e 1906 é a abrupta elevação do valor total das escrituras de até 10 contos de réis e sua participação, mais uma vez em termos de valor, no total das operações creditícias registradas no período. Mas direcionar-se-ia este fluxo para a cafeicultura? No dizer de Teodoro, do total de empréstimos no 
valor de até 10 contos efetuados entre 1880 e 1914, registrados no Tabelionato de 20 Ofício de Franca, apenas 313:845\$534, ou $29 \%$ das dívidas firmadas correspondiam aos lavradores como devedores, de um total de 1.074:031\$902. Os comerciantes firmaram dívidas, se considerarmos apenas estas quantias de até 10 contos, em um montante de 140:100\$480, ou 13\% do total. 0 restante dos empréstimos se referia a devedores com ocupação indeterminada, a um expressivo número de profissionais liberais e a elementos designados genericamente como "proprietários". ${ }^{29}$ Tanto estes "proprietários" quanto os devedores, cuja ocupação não é discriminada, nas escrituras caberiam na classificação de comerciantes ou de lavradores. M as como analisá-los na falta de informações mais precisas?

Teodoro também ressal ta que para estes empréstimos com valor de até 10 contos, a proporção de imóveis urbanos dados em garantia (34\%) praticamente se emparelhava aos rurais (36\%) Se acrescermos a esta constatação o fato de que nos empréstimos de pequenas quantias em que a ocupação dos devedores definiu-os como lavradores, e apenas 34:085\$800, ou 11\% se firmaram com garantia hipotecária de imóveis urbanos, concluiremos que o tipo de bem dado em garantia é um bom índice da origem do tomador. Assim, se já sabíamos que a proporção de lavradores captando esses empréstimos era de $29 \%$, e de pequenos comerciantes $13 \%$, podemos dividir o restante entre ambas as categorias de devedores, resultando em um montante de $58 \%$ para os pequenos proprietários rurais e $42 \%$ para os pequenos proprietários urbanos.

Estes dados indicariam uma lucratividade maior da pequena cafeicultura? Teodoro, a fim de tentar dar uma resposta a esta questão, analisa as condições de alguns desses empréstimos, como o contrato registrado no 20 Tabelionato de N otas de Franca no ano de 1900, entre o Dr. M arcílio M ourão, capitalista, e Joaquim Antonio de Andrade, lavrador, em que aquele efetua um empréstimo a este no valor de 2:100\$000, a $1,5 \%$ de juros ao mês com capitalização semestral (os pagamentos deveriam realizar-se de seis em seis meses) e garantia de 300 arrobas de café. M as o importante nessa escritura reside no fato de o escrivão observar que o credor receberia 15 quilos 
pelo preço de 10 que vigorasse em Santos. ${ }^{30}$ No mesmo teor era o contrato entre Olívio Alves Ferreira, capitalista, e José U rias do N ascimento, lavrador, em que aquele emprestou a este a quantia de 6:000\$000 com garantia sobre 900 arrobas de café que deveria entregar na estação da M ogiana, limpo e beneficiado; o devedor pagaria uma arroba por cada 10 quilos, ou melhor, pagaria a dívida com cada arroba de café valendo 10 quilos. ${ }^{31}$ Analisando mais alguns contratos nos quais o beneficiamento do café ficaria a cargo do devedor, Teodoro demonstra que se os cafeicultores em geral se encontravam numa posição de subordinação aos usurários urbanos, em maior grau estariam ainda os pequenos proprietários. $^{32}$

M as como se explica então o vigor demonstrado pela pequena propriedade? Analisando o inventário do mesmo Joaquim Antonio de Andrade, ${ }^{33}$ que contratara empréstimo com Marcílio Mourão em 1900, Teodoro nota não apenas que o devedor realizara poucas despesas monetárias com 0 café (possuía 3 mil cafeeiros), já que não empregava nenhum trabalhador no trato deste, como também dedicava-se à produção de animais, possuía um pomar, além de haver a possibilidade de cultivar outros gêneros alimentícios, de modo a pelo menos no quesito subsistência estar bem suprido. Ademais, pelos dados constantes do inventário, a dívida com Marcílio M ourão chegou a $608 \$ 620$ em 1902, indicando que os herdeiros do devedor reuniam condições razoáveis de solvência, reduzindo o seu débito a menos de um terço do valor original em apenas dois anos. ${ }^{34}$

Evidencia-se, portanto, que as pequenas propriedades produtoras de café, notadamente aquelas em que se utilizava apenas o trabalho familiar, ao contrário das médias e grandes propriedades, orientavam suas atividades primariamente para a subsistência e somente secundariamente para o mercado. É provável se inseriam neste para conseguir acesso a alguns dos bens que não podiam produzir, como ferraduras, utensílios agrícolas, algum vestuário, etc. Se a pequena cafeicultura por um lado mostrava-se menos lucrativa que aquela de maiores proporções, por outro possuía um poder de sobrevivência muito maior, tanto que não apenas atravessou os anos de crise, mas a 
permanência de um expressivo número de operações de crédito situadas em um valor de até 10:000\$000 entre 1906 e 1914 denota que a pequena propriedade poderia coexistir com as médias, e quiçá com as grandes propriedades.

Por conseguinte, sem a pequena cafeicultura e o pequeno comércio, provavelmente os grandes comerciantes-usurários do meio urbano (dada a dificuldade de se distinguir com clareza como polarizavam ambas as atividades) que certamente concentravam os resultados da acumulação de capital nessa economia, ${ }^{35}$ não poderiam manter um nível de lucratividade mínimo, sem o qual dificilmente se impediria a fuga desses capitais, bem como o deslocamento das atividades desse estrato de financistas para outras regiões (talvez na fronteira?), e conseqüentemente a evasão de seus recursos.

O papel da pequena cafeicultura torna-se ainda mais dilatado se pensarmos que o pequeno comércio citadino poderia se sustentar em parte devido ao consumo de artigos por setores do próprio meio urbano (como a ferrovia, que demanda uma série de empregados para funcionar, e a produção de determinados artigos, ainda realizada em base artesanal) que desfrutavam de uma relativa autonomia em relação ao comportamento da lavoura cafeeira, mas também em razão do consumo dos pequenos lavradores e daquelas fazendas de café de maior porte que conseguiram sobreviver. ${ }^{36}$

Como os níveis de lucratividade dos agentes responsáveis pelo financiamento da lavoura cafeeira se mantiveram (ou ao menos não se reduziram drasticamente), as fazendas de maiores proporções, assim que o mercado cafeeiro acenou com uma conjuntura mais favorável a partir de 1907, puderam retomar a atividade cafeeira, ou por meio de novos investidores ou por meio de alguns proprietários de maior porte que conseguiram resistir à crise. Durante a crise, o sistema continuou funcionando graças às mudanças verificadas no circuito do crédito. Nossa análise documental evidencia a entrada do pequeno produtor e a prática do pequeno crédito nesse circuito, contudo, isto não permite afirmar que todos os médios cafeicultores estivessem excluídos do sistema de crédito. Na medida em que as condições se tornaram favoráveis, especialmente a partir do plano de 
valorização, o circuito de crédito pôde ser redirecionado às unidades de maiores proporções e de maiores escalas de produção, a despeito da continuidade das operações creditícias envolvendo pequenos produtores.

Perante as condições adversas da crise, muitos cafeicultores sucumbiram; entretanto, algumas estratégias de sobrevivência permitiram que alguns desses fazendeiros atravessassem 0 período compreendido entre 1898 e 1906. Existiam movimentos complexos. Nas fazendas de maior porte, numa conjuntura adversa, os custos geravam impactos extremamente negativos. Como alternativa de redução destes impactos, 0 que a documentação consultada nos permite afirmar é que as formas de rebaixamento dos custos monetários na cafeicultura em crise foram sendo radicalizadas. "É o caso de João de Pádua Pedroso, que ao contratar em regime de parceria os italianos Santo Baptistoni e Pio Dionísio, cedeu aos 'parceiros' um alqueire de terra aonde poderiam plantar cereais, além de terras para a criação de gado e porcos." ${ }^{37}$ Esta escritura foi lavrada em 1902, num dos momentos mais críticos da superprodução, e além da produção de alimentos, os colonos, durante quatro anos, teriam direito à metade da produção dos 13.000 cafeeiros. M esmo sob a vigência de um sistema de parceria, o trabalhador ainda poderia produzir outros gêneros alimentícios que não o café. De uma forma geral, os contratos de parceria versavam sobre lavouras já formadas, o que certamente reduziria a possibilidade de os colonos praticarem 0 cultivo de alimentos nos espaços intercafeeiros; entretanto, nestes casos, o fazendeiro cedia um terreno extra para compensar tal perda.

Nos contratos de colonato, até utilizando-se de vários elementos para reduzir os gastos em dinheiro necessários à formação das lavouras, conforme vimos acima, alguma quantia, mesmo que diminuta, era gasta. Todavia, na escritura acima citada, o fazendeiro não desembolsaria nenhum dinheiro (exceto eventuais adiantamentos, compra de ferramentas, remédios, produtos de armazém, etc.), além do que liquidaria seus débitos com o colono com a metade da produção de café, produto com preços altamente deprimidos naquele contexto. Com a parceria os cafeicultores desfaziam-se de dois problemas: reduziam seus 
gastos monetários necessários à manutenção da lavoura e livravam suas "tulhas" de estoques indesejáveis. Foram estas as estratégias utilizadas pelos cafeicultores para minimizar a perda patrimonial que se seguiu à superprodução do final do século XIX e às políticas contracionistas implementadas a partir do governo Campos Salles.

M esmo assim, após 1898 os cafeicultores de maior porte ainda deveriam saldar as dívidas firmadas no período anterior, a fim de minimizar a perda de patrimônio e tentar expandir a parcela dos lucros que Ihes cabia. Além do monopsônio na compra dos alimentos produzidos pelos trabalhadores, que outras formas havia de incrementar os ganhos do cafeicultor?

Em uma dissertação de mestrado sobre a atuação de Costa Machado, um eminente cafeicultor de São José do Rio Pardo, Fábio Augusto Missura, nos mostra alguns casos em que 0 fazendeiro conseguia levar adiante suas atividades econômicas sem 0 uso ostensivo da moeda. Analisando 140 cadernetas de contas de colonos de uma das fazendas de Costa M achado, a Vila Costina, entre 1891 e 1892, o autor demonstra uma situação de endividamento de todos estes para com 0 fazendeiro, endividamento oriundo principalmente dos gastos dos trabalhadores no armazém da fazenda. M as o colono não poderia escapar a esta armadilha simplesmente buscando adquirir os artigos de que precisava de outras fontes, como os comerciantes da cidade? Vejamos o que afirma M issura:

Os colonos tinham liberdade para fazerem suas compras onde preferissem. 0 fazendeiro, por sua vez, procurava controlar 0 monopólio de seu negócio, evitando que nenhum concorrente se estabelecesse na vizinhança. $\mathrm{Na}$ fazenda Vila Costina desenvolveu-se um artifício bastante curioso como forma de manter o colono preso ao armazém e à farmácia (havia uma farmácia dentro da fazenda): criou-se uma espécie de moeda interna, que o colono recebia como vale; como esse vale dificilmente era aceito na cidade o trabalhador não tinha outra alternativa a não ser gastá-lo no armazém da própria fazenda. ${ }^{38}$

N este ponto observamos duas formas de achatar os custos monetários das operações de uma fazenda de café: primeira, 
superexplorando os colonos, posto que na medida em que se atingia um monopólio mercantil em relação a estes, abria-se ao cafeicultor a possibilidade de elevar sobremaneira o preço dos produtos vendidos a seus empregados, impingindo-lhes uma situação de endividamento que dificilmente se contornaria; segunda, dispensando a utilização de moeda nas relações entre 0 fazendeiro e seus colonos. Entretanto, se pensarmos no conjunto das relações travadas pelo cafeicultor, devemos indagar sobre a forma como este obtinha os produtos que vendia em seu armazém. Há apenas uma possibilidade: estes produtos saíam diretamente dos estabelecimentos comerciais das cidades para a fazenda, o que exige mais uma pergunta: Como o fazendeiro pagava por estes artigos? Certamente que se tratava de compras a prazo, mas até que ponto o comerciante poderia esperar pelos pagamentos em moeda? $\mathrm{N}$ a verdade, nestas transações havia mais uma forma de se minimizar o uso da moeda, que consistia em trocar alguns gêneros produzidos pelos colonos, como arroz, feijão e milho, por mercadorias que estes mesmos colonos necessitavam. ${ }^{39}$

A citação que extraímos do trabalho de Fábio Missura, evidentemente refere-se a uma grande propriedade, situada em São José do Rio Pardo, contudo não sabemos se estes procedimentos de estreitamento monetário se efetivavam também nas fazendas de médio porte. Existe a possibilidade, por exemplo, de alguns "vendeiros", ligados a fazendeiros ou não, organizarem o jogo das trocas num pequeno raio de ação que incluiria médias e pequenas propriedades. Mas mesmo que houvesse a possibilidade da efetivação desses estreitamentos monetários para os médios proprietários individualmente considerados, muitos, por não possuírem patrimônio para queimar, ou por já se encontrarem por demais onerados por dívidas contraídas no período anterior, não conseguiriam escapar dos efeitos da crise.

A partir de 1897/1898 percebemos, nas escrituras de contratos de café, que a transição das relações de colonato para as de parceria já estava em curso, ${ }^{40}$ ainda que uma parcela dos fazendeiros optasse por dar continuidade às remunerações em dinheiro, talvez temendo as multas estabelecidas nos contratos de 
colonato. Portanto, a superação da crise para cada cafeicultor dependia de sua situação anterior de endividamento, da extensão de seu patrimônio, e mesmo de suas decisões de investimento. Demonstremos:

Antonio de Moraes Ribeiro, falecido em 1902, ${ }^{41}$ é um exemplo de cafeicultor de pequeno para médio porte que não reuniu condições de sobrevivência ante a crise. Em seu inventário constavam móveis no valor total de 3:910\$000, benfeitorias em sua fazenda, denominada "Japão", no montante de 8:100\$000, entre as quais nove casas para colonos cobertas de zinco, mais 36.000 pés de café formados no valor de 32:400\$000, 100 alqueires de campos no valor de 6:000\$000, 37 alqueires de capoeirão grosso montando a 9:250\$000, 20 alqueires de culturas em pasto avaliados por 3:000\$000, 50 alqueires de culturas em invernada de capim jaraguá e gordura por 7:500\$000, 5 mil covas com café plantado em 1902 avaliados por $250 \$ 000$ (perceba-se que cafeeiros estavam sendo formados durante a crise), mais 15 alqueires de terras de culturas fechadas e ocupadas pelo café avaliadas por 2:250\$000, além dos frutos pendentes do café calculados em 800 arrobas e avaliados em $800 \$ 000$.

Estimava-se um número medíocre de frutos a produzir, apenas 800 arrobas, uma quantidade muito aquém das potencialidades de 36.000 pés de café. Na verdade, segundo a produtividade estimada por Tosi para Franca no ano de 1902, de 154,2 arrobas por mil pés, ${ }^{42}$ a fazenda Japão poderia produzir $5.551,2$ arrobas nesse ano de 1902. Neste caso, por que a estimativa de colher apenas 800 arrobas? Ora, no inventário também se encontram referências a casas para colonos, mas nenhum indício de dívidas para com estes ou com parceiros. Se havia trabalhadores na fazenda em 1902 ou nos anos anteriores, diante da crise provavelmente foram dispensados e não haveria quem colhesse todos os frutos produzidos, de tal forma que estes apodreceriam nos pés. Observando as terras que possuía o inventariado, também verificamos que parte delas ( 15 alqueires) já se encontrava ocupada pelo café, restando cerca de 207 alqueires a ocupar, entre terras de campos, capoeirão, etc. Se a viúva conseguisse vender suas terras ao preço constante da 
avaliação feita no inventário, poderia angariar fundos para financiar as atividades em sua fazenda.

Apesar desse quadro adverso, M aria Lemes Ribeiro, viúva de Antonio de Morais Ribeiro, poderia dar prosseguimento à produção de café em sua fazenda - já que os filhos eram menores de idade - financiando suas atividades vendendo parte de suas terras, não fosse a existência de dívidas mais antigas que seu marido não saldara. Três credores declararam possuir dinheiro a receber do finado, o que foi prontamente confirmado pela viúva. 0 coronel Joaquim Ferreira Ribeiro deveria receber 10:800\$000, mais 11:159\$000 de juros acumulados a uma taxa de $8 \%$ ao ano; José Antonio Ribeiro, pai do finado, 9:000\$000, sem qualquer taxa de juros, e dona Helena Nogueira da Silva Moraes, 2:500\$000 mais 3:900\$000 de juros acumulados a uma taxa de $10 \%$ ano, de forma que a dívida total para com esses três credores e herdada por M aria Lemes Ribei ro montava a 37:359\$000.

Aparentemente não havia nenhum documento comprobatório da dívida, já que o curador de órfãos exigiu 0 depoimento de algumas testemunhas que reconhecessem a existência das dívidas ( o que demonstra também o peso dos laços de confiança nas relações creditícias), que, de fato, foram arroladas e confirmaram inclusive o seu valor total. As obrigações financeiras da viúva para com os credores, no entanto, foram recalculadas pelo contador Francisco Baldoíno de M oraes, que as situou, incluindo algumas despesas de $M$ aria Lemes Ribeiro com negociantes e médicos, em 32:525\$250.

$\mathrm{Na}$ partilha 0 juiz destinou alguns bens para o pagamento dos compromissos herdados por Maria Lemes Ribeiro, compostos pelos 36.000 pés de café formados e que, segundo as declarações constantes do inventário, encontravam-se em bom estado, e mais a terra onde estes se encontravam, composta de 15 alqueires. Entretanto, Maria Lemes Ribeiro solicitou ao juízo a adjudicação da dívida, que pelo teor do documento provavelmente referia-se à sua renovação. Os credores concordaram, e no dia cinco de maio de 1904 Maria Lemes Ribeiro e o coronel Joaquim Ferreira Ribeiro, residente em São João Baptista do Arrozal do Pirahy, Estado do Rio de Janeiro, lavraram escritura de dívida em favor deste último no valor de 
$32: 525 \$ 250$, a ser paga no prazo de seis anos com uma taxa de juros de $6 \%$ ao ano, condições favorabilíssimas, como podemos perceber. Entretanto, nem sequer assim Maria Lemes Ribeiro conseguiu reerguer os negócios de seu finado marido, tanto que por ocasião do vencimento do empréstimo, no ano de 1910, requereu ao juiz de direito a expedição de edital para venda em hasta pública de todas as suas terras e de seus filhos, segundo sua alegação, para arcar com o pagamento da dívida.

O grande problema enfrentado pareceu residir no financiamento, pois além de não lucrar com a venda de café da safra de 1902, à viúva estava vedada a obtenção de recursos por meio da venda das terras que lhe couberam por partilha, já que todas elas foram hipotecadas, o que não lhe permitiu fazer frente aos compromissos assumidos com o coronel Joaquim Ferreira Ribeiro, e que provavelmente também Ihe obstou o recurso a novas fontes de crédito, não conseguindo assim obter meios materiais para prosseguir com a produção de café, mesmo após o plano de valorização de 1906.

\section{CONSIDERAÇÕES FINAIS}

Ao final do percurso esperamos ter logicamente explicitado o papel fundamental assumido pela pequena cafeicultura ${ }^{43}$ na sustentação e viabilização do complexo cafeeiro, em especial nos momentos de dificuldades de realização da produção. Adotamos aqui uma visão de conjunto, buscando rastrear os pontos de contato entre a produção, a circulação e a acumulação, bem como as formas pelas quais as pequenas propriedades se inseriram em tal circuito. Ao adotar uma visão de conjunto, múltiplos desafios se apresentaram, entre eles, rastrear as dificuldades enfrentadas pelas propriedades de maior porte, levando-nos diretamente a analisar o mundo da produção, que ao contrário dos ruídos provocados pela circulação, em geral oculta seus movimentos. Difícil perceber as realidades vivenciadas entre fazendeiros e colonos no espaço circunscrito pela porteira, uma vez que as relações travadas entre ambos 
foram marcadas por complexos mecanismos de expropriação que extravasavam as cláusulas registradas em contrato.

Difícil também é perceber os pontos de contato dessas relações com um conjunto econômico mais amplo, dificuldade que só pôde ser superada quando nos defrontamos com a acumulação de capital e deparamos com a figura dos comissários e usurários urbanos que, tal qual o fazendeiro, em seu próprio espaço, estabeleciam na cidade, no processo de financiamento da lavoura, uma relação, em que 0 fazendeiro se tornava 0 expropriado.

As dificuldades aumentaram ainda mais quando se percebeu o silêncio da bibliografia em relação ao universo da pequena cafeicultura. Como era financiada? Como produzia? Este silêncio precisa ser superado, pois a pequena propriedade esteve presente no cenário rural do complexo cafeeiro. Nada mais fizemos aqui do que eleger um espaço em que a pequena propriedade foi preponderante, e isto nos possibilitou observá-la de maneira mais clara. Possivelmente o peso da pequena cafeicultura tenha sido considerável também em outros municípios, existindo aí a possibilidade de estudos futuros.

Geralmente a questão da pequena propriedade aparece na bibliografia relacionada à da ascensão social dos imigrantes, notadamente italianos, residindo aí o marco inicial de uma estrutura fundiária mais fragmentada. Discordamos desta afirmação para o caso estudado, pois percebemos, pelas evidências coletadas, que os imigrantes submetiam-se a desvantajosos contratos de trabalho e reuniam poucas possibilidades de angariar algum pecúlio, sobretudo em momentos de crise.

Paradoxalmente, é justamente na crise que se percebe um processo mais acelerado de fragmentação da terra, ligado mais às dificuldades dos fazendeiros do que à frugalidade, ética ou capacidade de poupança dos colonos. M esmo quando o colono imigrante (ou não) tornava-se proprietário, a pequena cafeicultura, como demonstramos, reunia parcas possibilidades de acumulação, pois se submetia ao jugo dos usurários num grau de exploração ainda mais elevado do que o praticado com os grandes proprietários. É necessário distinguir entre acesso à terra 
e ascensão social, porque uma coisa não necessariamente implica outra; os pequenos proprietários, quanto ao "enriquecimento", talvez enfrentassem dificuldades maiores do que alguns colonos, notadamente aqueles situados na crista da fronteira, onde as condições de produtividade do café e do cultivo alimentício intercafeeiro eram superiores.

Difíceis são os desafios apresentados por esta nova perspectiva, entretanto começaríamos bem se documentalmente abandonássemos a "fixidez" dos inventários e acolhêssemos a perspectiva dinâmica potencialmente presente nos livros cartoriais.

TOSI, Pedro Geraldo; FALEIROS, Rogério Naques; TEODORO, Rodrigo da Silva. Fragments of a Model: The small farmings of coffee and accumulation of capitals. Franca/São Paulo 1890-1914. História, São Paulo, v.24, n.2, p.291-327, 2005.

ABSTRACT: This article turns on the importance of the small coffee production in the coffee complex economy between 1890 and 1914. We argue here the relations of work, the forms of financing and the way as the small coffee production inserts itself in this universe. We use as priority sources the employment contracts that involved the formation and/or the treatment of coffee trees and the Writes of mortgage debts, both recorded in Notarial Books, documents not used by historiography in a systematical way. We turn our look for a region marked predominantly for small and middle producing farms of coffee, observing the dynamics of accumulation in a period of expansion and crisis of the coffee economy.

KEYWORDS: Coffee Economy; Accumulation; Work;

\section{NOTAS}

\footnotetext{
* Professor do Departamento de Educação, Ciências Sociais e Política Internacional da UNESP - Campus de Franca. Doutor em Economia Aplicada (Área de Concentração: História Econômica) pelo Instituto de Economia da UNICAMP. e-mail: pgtosi@uol.com.br CEP 14400-690
} 
** Doutorando em Economia Aplicada (Área de Concentração: História Econômica) pelo Instituto de Economia da UNICAMP. Bolsista FAPESP. email: rogerionaques@yahoo.com.br.CEP 13083-970

*** Doutorando em História Econômica pela FFLCH/ USP. e-mail: rodrigostst@yahoo.com.br. CEP 13083-970

${ }^{1}$ Entendemos o complexo cafeeiro como um conjunto de atividades integradas entre si, tais como: comércio de exportação e importação, transporte ferroviário, produção de alimentos, ensacamento, beneficiamento, constituição de uma infra-estrutura urbana, financiamento, enfim, todas as atividades necessárias à produção e comercialização do café, nucleadas pela produção cafeeira e que se incrementaram mutuamente, reforçando o ritmo da acumulação.

${ }^{2}$ TEODORO, Rodrigo da Silva. O Crédito no mundo dos senhores do café. Franca 1885-1914. Campinas, 2006. Disserteção (Mestrado) - Instituto de Economia, UNICAMP, fl.81.

${ }^{3}$ Almanach Illustrado de Ribeirão Preto. Ribeirão Preto: Sá, Manaia \& Cia, 1914, não paginado. Arquivo Histórico Municipal de Ribeirão Preto.

4 Também colaborou para esta fragmentação a inexistência ou o pequeno número de casamentos consangüíneos, tal qual ocorreu na vertente de povoamento que Lucila Brioschi e outros (BRIOSCHI, Lucila Reis; et. alli. Entrantes no sertão do Rio Pardo: o povoamento da Freguesia de Batatais século XVIII/XIX. São Paulo: CERU, 1991, p.72) chamaram de Rio Pardo (na região onde hoje se encontra o município de Ribeirão Preto e outros), onde estes parecem haver funcionado como uma estratégia de se manter a propriedade no interior do grupo familiar, permitindo a sua concentração ao longo do tempo. Na verdade, este é um assunto muito complexo e que exigiria estudos específicos e mais aprofundados, mas é inegável a maior fragmentação da estrutura fundiária de Franca em comparação a outras.

${ }^{5} \mathrm{O}$ derrame de lavas basálticas ocorrido na bacia do Paraná foi o mais extenso do globo, com uma área estimada entre 800.000 e $1.000 .000 \mathrm{Km}^{2}$. Esparramase por boa parte dos estados de São Paulo, Santa Catarina, Paraná e Rio Grande do Sul, entretanto, cabe salientar a existência de uma alternância entre a sedimentação do arenito e derrames basálticos (lavas), estruturando o relevo em camadas (trata-se aqui de um vulcanismo de fissura, ou seja, as lavas basálticas irrompiam através de falhas e fraturas, inundando rapidamente as depressões existentes nos lençóis de areia, formando amplos lagos de rocha fundida que, ao consolidar-se, transformavam-se em vastas planícies negras. Esses derrames basálticos migravam de um para outro sistema de fraturas, devido ao tipo de atividade vulcânica que os originou, aflorando de maneira descontínua na superfície). Sob condições climáticas diversas ao longo do tempo geológico, as rochas basálticas provenientes desses derrames se transformaram num solo que, embora pobre em recursos minerais, é de 
excelente qualidade agrícola - a terra roxa (...). Devido ao afloramento ocasional das camadas, os solos de terra roxa legítima (diabásios, meláfiros calcíferos e basáltitos), também chamada de encaroçada, resultado do intemperismo das rochas basálticas, ocupam áreas esparsas constituindo as conhecidas 'manchas de terra roxa'. Sua ocorrência varia de 2,0\% a 2,5\% no território paulista, ou seja, de 5.000 a $6.000 \mathrm{Km}^{2}$. É encontrada somente nas vertentes onde afloram as camadas de basalto; mais raramente nos planaltos. São os solos característicos de Cravinhos, Ribeirão Preto e seus arredores, com terrenos que propiciam o desenvolvimento da cafeicultura.

${ }^{6}$ LEVI, Darrell Erville. A Família Prado. São Paulo: Cultura Livraria e Editora, 1977 , p. 165 .

${ }^{7}$ Segundo os dados de José Francisco de Camargo, em 1905 a média de cafeeiros por propriedade era de 84.324 em Ribeirão Preto, 80.029 em São Carlos, 44.490 em Campinas, 29.973 em Jaú e 18.276 em Franca. Evidentemente existiam pequenas unidades produtoras de café em todos estes municípios, entretanto, nos casos de Ribeirão Preto, São Carlos e Campinas, as grandes propriedades "puxavam" a média de cafeeiros por estabelecimento para cima, o que não ocorria em Franca, corroborando nossa hipótese de que neste município, pelos motivos acima expostos, não existiam grandes fazendas em termos de produção cafeeira por isso, a reduzida média de pés de café por estabelecimento se comparada a outros municípios. Não se tratava da inexistência da pequena cafeicultura em Ribeirão Preto, Campinas e São Carlos, mas da inexistência de grandes lavouras em Franca. Para destacar o caráter periférico da cafeicultura francana no cenário do "oeste" paulista, apresentamos o número de cafeeiros cultivados nestes municípios em 1905: 29.094.365 em Ribeirão Preto, 28.518.100 em Campinas, 24.049.365 em São Carlos, 22.749.494 em Jaú e 7.380.988 em Franca. CAMARGO, José Francisco de. Crescimento da população no estado de São Paulo e seus aspectos econômicos. São Paulo: IPE/USP, 1981, p.92-133.

${ }^{8}$ CAMARGO, José Francisco. Op. cit., p.40-2.

9 SALLUM JR., Brasílio. Capitalismo e cafeicultura. Oeste Paulista 1888-1930. São Paulo: Duas cidades, 1982, p.145-167.

${ }^{10}$ FALEIROS, Rogério Naques. Homens do Café: Franca 1880-1920. Campinas, 2002. Dissertação (Mestrado) - Instituto de Economia, UNICAMP.

${ }^{11}$ Idem, fl.189.

${ }^{12}$ É necessário destacar que se trata apenas de uma grosseira inferência, pois não consideramos os gastos com transporte, ensacamento, armazenamento, etc. Também não consideramos a atuação de intermediários, que drasticamente reduziam os valores recebidos pelos fazendeiros. Por outro lado, consideramos a cotação do ano de 1902, acentuadamente deprimida em relação ao passado por conta da crise de superprodução. De qualquer forma, acreditamos que os cálculos feitos acima demonstram, ainda que de forma 
aproximada, a alta lucratividade proporcionada aos fazendeiros que estabeleciam o regime de colonato.

${ }^{13}$ HOLLOWAY, Thomas H. Imigrantes para o café: café e sociedade em São Paulo 1866-1934. Rio de Janeiro: Paz \& Terra, 1984, p.122.

${ }^{14}$ Livro de Notas n. 56, fls.84-6. $1^{\circ}$ Ofício Civil de Franca. (FALEIROS, Rogério Naques. Op. cit., fl.184.

${ }^{15}$ Cf. Inventário de Joaquim Garcia Lopes da Silva Júnior. Caixa 139 do Tabelionato de $1^{\circ}$ Ofício, 1911, volume 66, Arquivo Histórico Municipal de Franca. TEODORO, Rodrigo da Silva. Op. cit., cap. III.

${ }^{16}$ CANO, Wilson. Raízes da concentração industrial em São Paulo. Campinas: IE, UNICAMP, 1998, p.72.

${ }^{17}$ FALEIROS, Rogério Naques. Fronteiras do Café: fazendeiros e colonos no interior paulista (1917-1937). Doutorado IE/UNICAMP. Relatório Parcial de Pesquisa FAPESP n.01 (mimeo), 2005.

${ }^{18}$ CAMARGO, José Francisco. Op. cit., v.I.

19 RAMOS, Augusto. O café no Brasil e no Estrangeiro. Contribuição comemorativa do $1^{\circ}$ Centenário. Rio de Janeiro: Papelaria Santa Helena, 1923, p.204-05.

${ }^{20}$ TOSI, Pedro Geraldo. Capitais no interior: Franca e a história da Indústria coureiro-calçadista (1860-1945). Franca: UNESP/FHDSS, 2003, p.144.

${ }^{21}$ Idem, p. 138.

${ }^{22}$ SAES, Flávio Azevedo Marques de. Crédito e Bancos no desenvolvimento da economia paulista: 1850-1930. São Paulo: IPE/USP, 1986, p.112-123.

${ }^{23}$ CARVALHO FRANCO, Maria Sylvia. Homens livres na ordem escravocrata. 2.ed. São Paulo: Ática, 1974, p.160-171.

${ }^{24}$ (SAES, Flávio Azevedo Marques de. Op. cit., p.70-1.

${ }^{25}$ MARCONDES, Renato Leite. O Financiamento hipotecário da cafeicultura no Vale do Paraíba Paulista (1867-87). Revista Brasileira de Economia, v.56, n.1, p.147-170, 2002.

${ }^{26}$ Conforme assinala Carlos G. Guimarães, bastou uma mudança na direção seguida pela política monetária para que todo o setor comercial e creditício da cidade do Rio sofresse sérios abalos. Visando valorizar a o câmbio, o governo diminuiu a quantidade de papel-moeda emitido, cujo total (incluindo o papelmoeda posto em circulação pelos bancos), de um patamar de 192.527:000 $\$ 000$ em 1870 passou a 181.868:000 $\$ 000$ em 1875. GUIMARÃES, Carlos Guilherme. O Banco Rural e Hipotecário do Rio de Janeiro e o pós-guerra do Paraguai, 1871-1875. Anais do V Congresso Brasileiro de História Econômica e $6^{a}$ Conferência Internacional de História de Empresas (ABPHE). Caxambu, 2003, p.29.

${ }^{27}$ Redesconto: operação bancária em que uma instituição financeira desconta títulos (duplicatas, promissórias, etc.) que já foram anteriormente descontados por outra instituição. É uma operação que permite, à primeira casa bancária, 
fazer caixa para novos negócios, sem ficar imobilizada à espera do vencimento dos títulos. SANDRONI, Paulo. Dicionário de Economia. São Paulo: Abril Cultural, 1985, p.363.

28 Conforme a definição de Renato M. Perissinotto, o "Grande Capital Cafeeiro" engloba os agentes econômicos que se caracterizavam por uma larga diversificação de seus investimentos: comércio de exportação e importação, atividade bancária, indústria, estradas de ferro, empresas de serviços públicos, etc. PERISSINOTTO, Renato Monseff. Classes Dominantes e Hegemonia na República Velha. Campinas: Editora da Unicamp, 1994, p.37-44.

29 TEODORO, Rodrigo da Silva. Op. cit., cap. III.

${ }^{30}$ Livro de Notas n. 36, fls. 14. $2^{\circ}$ Ofício Civil de Franca. 1900. TEODORO, Rodrigo da Silva. Op. cit.

${ }^{31}$ Livro de Notas n. 36, fls. 16. $2^{\circ}$ Ofício Civil de Franca. 1900. TEODORO, Rodrigo da Silva. Op. cit.

${ }^{32}$ Idem, cap.I.

${ }^{33}$ Inventário de Joaquim Antonio de Andrade. v.58, Caixa 138, 1902, v.58. Arquivo Histórico Municipal de Franca. Idem, cap. III.

${ }^{34}$ Idem, cap.III.

${ }^{35}$ Idem, cap.I e II.

${ }^{36}$ Em todo o complexo cafeeiro a presença dos pequenos produtores de café foi significativa, de modo que os mecanismos que expusemos aqui para Franca poderiam atuar também em outros municípios. A diferença é que grandes cafeicultores (inexistentes em Franca) poderiam resistir de forma diversa na crise, seja porque encontrassem menores dificuldades para diversificar seus negócios, seja porque possuíssem maior patrimônio para queimar.

${ }^{37}$ Livro de Notas n.86, fls.35-7. $1^{\circ}$ Ofício Civil de Franca. 1902. FALEIROS, Rogério Naques. Homens do Café: Franca 1880-1920. Campinas, 2002. Dissertação (Mestrado) - Instituto de Economia, UNICAMP, fl.192.

38 MISSURA, Fábio Augusto. Costa Machado: ação política e empresarial na sociedade do café em Rio Pardo (1877-1917). Franca, 2003. Dissertação (mestrado em história). -FHDSS, Unesp, fl.46-47.

${ }^{39}$ TEODORO, Rodrigo da Silva. Op. cit., cap. III.

${ }^{40}$ FALEIROS, Rogério Naques. Op. cit., fl.190-191.

${ }^{41}$ Inventário de Antonio de Moraes Ribeiro. Caixa 35 do Tabelionato de $1^{\circ}$ Ofício, 1902, volume 85. Arquivo Histórico Municipal de Franca. TEODORO, Rodrigo da Silva. Op. cit.

${ }^{42}$ TOSI, Pedro Geraldo. Op. cit., p.132.

${ }^{43}$ Notadamente aquelas nas quais se utilizava apenas o trabalho familiar e que não possuíam mais que 15.000 cafeeiros.

Artigo recebido em 05/2006. Aprovado em 07/2006 